УДК 72.03

ББК $85.101 ; 63.3(0) 32$

DOI:10.18688/aa155-1-14

Thomas Noble Howe

Paolo Gardelli

\title{
The Archaeological Park at Stabiae: a Regional Interdisciplinary and Sustainable Approach
}

\section{The unusual character of the Stabiae site:}

The site of Stabiae is a very unusual archaeological site. Lying just four kilometers from Pompeii (fig. 1), it was buried in the same eruption of Vesuvius in AD 79, and as a result is stunningly well-preserved. But rather than being a small town site or small farming villa, it is a collection of five or six enormous seaside villas, up to 22.000 square meters each ${ }^{1}$, the largest concentration of elite, seaside well-preserved villas in the entire Mediterranean.

It was not just a site of great luxury or great art: it is the best-preserved example of one of the most important seats of political power and architectural art during the formation of the Roman Empire. In the last century of the Republic the senatorial elite gathered around the villas which lined the Bay of Naples and in certain months these villas in fact displaced Rome as the center of political activities of the senatorial elite. In AD 27 the capital actually did move there when Tiberius withdrew to his villas on Capri for the rest of his reign. Pliny the Elder - not a senator but an equestrian imperial administrator - spent the night of the eruption in AD 79 at one of the villas of Stabiae (we don't know which one) and died on the beach the next morning in the last pyroclastic surge from Vesuvius [Plin. Epist. 6.16 (to Tacitus)]. These were not «resorts», but Power Houses, to use Andrew WallaceHadrill's term [18, pp. 43-54]²: «The Roman Villa was a power-house; at once the supreme symbol of the individual's power, resources and ability to control the environment and its population, and the place where that power was actively generated. It remains controversial the extent that one can identify the type of owner or his or her social class from the ruins of architecture or art alone. The Stabiae villas, from size and general quality of artwork seem generally well above the scale of the other luxury villas of the area, with the exception of those which are - tentatively - identified with senatorial or imperial owners (Villa of the Papyri; the so-called the Poppaei villa, or Villa of Poppaea, Oplontis)». Some of the most important events of the later Republic and early Empire occurred in the great villas around

\footnotetext{
1 The Villa San Marco, for example, as demonstrated by 2002 geophysical work by the RAS Foundation and 2006 sondage by the Soprintendenza. There is also a small town site which in 2009 was revealed to have at least one large luxury town-house on the model of those in Pompeii or Herculaneum, built on the out of use city wall after ca. $30 \mathrm{BC}$.
}

On the functions, and hence potential types of owners, see [2, p. 9-24]. 
the Bay. The only place in the Bay of Naples where the urbanistic layout of this type of villa is well preserved is Stabiae ${ }^{3}$.

\section{The Justification for new excavations}

In the shadow of Pompeii and Herculaneum: Oddly enough, the site attracted very little public or scholarly attention before 1998 when the first steps were made to form the Restoring Ancient Stabiae Foundation ${ }^{4}$. In order to justify new excavations in the Pompeii area, where there is already perhaps more material than can be successfully preserved ${ }^{5}$, one has to argue that the site of Stabiae is radically different from the Pompei-Herculaneum town sites, and new excavations will add new information. This is now generally accepted ${ }^{6}$. It also needs to be demonstrated that the site can be conserved and maintained.

The special opportunities of the Stabiae site: The site has unusual advantages. It is not only very well-preserved, even to the second storey of buildings, but has been open to the air only since 1950, and always under roof. It also represents a high quality art and innovative architecture, including garden architecture. Significant is the fact that the site is largely unencumbered with modern buildings, since it has been a protected archaeological zone since 1957 (demarked by the curving perimeter road, fig. 2) and the main villas, those open and those still buried, lie on state owned land. Therefore, unlike Herculaneum or Oplontis, it is possible to excavate entire villas in their totality. Also, large-scale excavations in the Pompeii area can be executed rather rapidly since being overburden with volcanic lapilli (cinder), and slow stratigraphic excavation is rarely necessary. Therefore, clearing three large complexes relatively rapidly is feasible, if full recording and conservation resources are at hand.

Most unusually, the Stabia site preserves the panoramic view of the sea and the mountains directly from the villas. The other large well-preserved maritime villas - Oplontis and the Papyri-are in deep, disorienting excavation pits, surrounded by drab modern sprawl, and overlain by modern buildings, and give no sense of the original relationship those villas had to the sea ${ }^{7}$. At Stabiae, to the rear (south), the terrain is still traditional agriculture, and would

3 This writer has put forward the argument that the pattern of villas at Stabiae, built in high density next to one another, continues the pattern of senatorial enclaves around Rome and Naples characteristic of the last century of the Republic into the first decades of the Empire [see: 9; 19 - in press for the acts of the conference: Paradigm and Progeny: Roman Imperial Architecture and Its Legacy].

$4 \quad$ The original excavations were abandoned in 1782 in part because the Royal excavators felt that Pompeii and Herculaneum held far more material of interest, and Stabiae has existed under the shadow of those two sites ever since. The site has largely existed under the shadow of the two much more famous sites until recently.

5 It is asserted that as much as $80 \%$ of the frescoes which were visible in Pompeii in the 1930s simply no longer exist: bleached, spalled off the walls, vandalized. In general this is not a precisely measureable figure [on the general degradation of Pompei - 1].

$6 \quad$ Only in the last few years has the scholarly world recognized that the Stabiae site is of a radically different character from those two famous town sites and other villa sites in the area, in good part because of the work of the Restoring Ancient Stabiae Foundation. A recent book recognizes that the largest villas are a distinct cultural phenomenon and presents a close analysis of five of the best preserved large villas, three of which are at Stabiae [20].

$7 \quad$ Only recently has geophysical work at Oplontis, organized by Prof. John Clarke of the University of Texas, demonstrated for certain that Oplontis too was also directly on the sea front, built on a low cliff overlooking the Bay. 

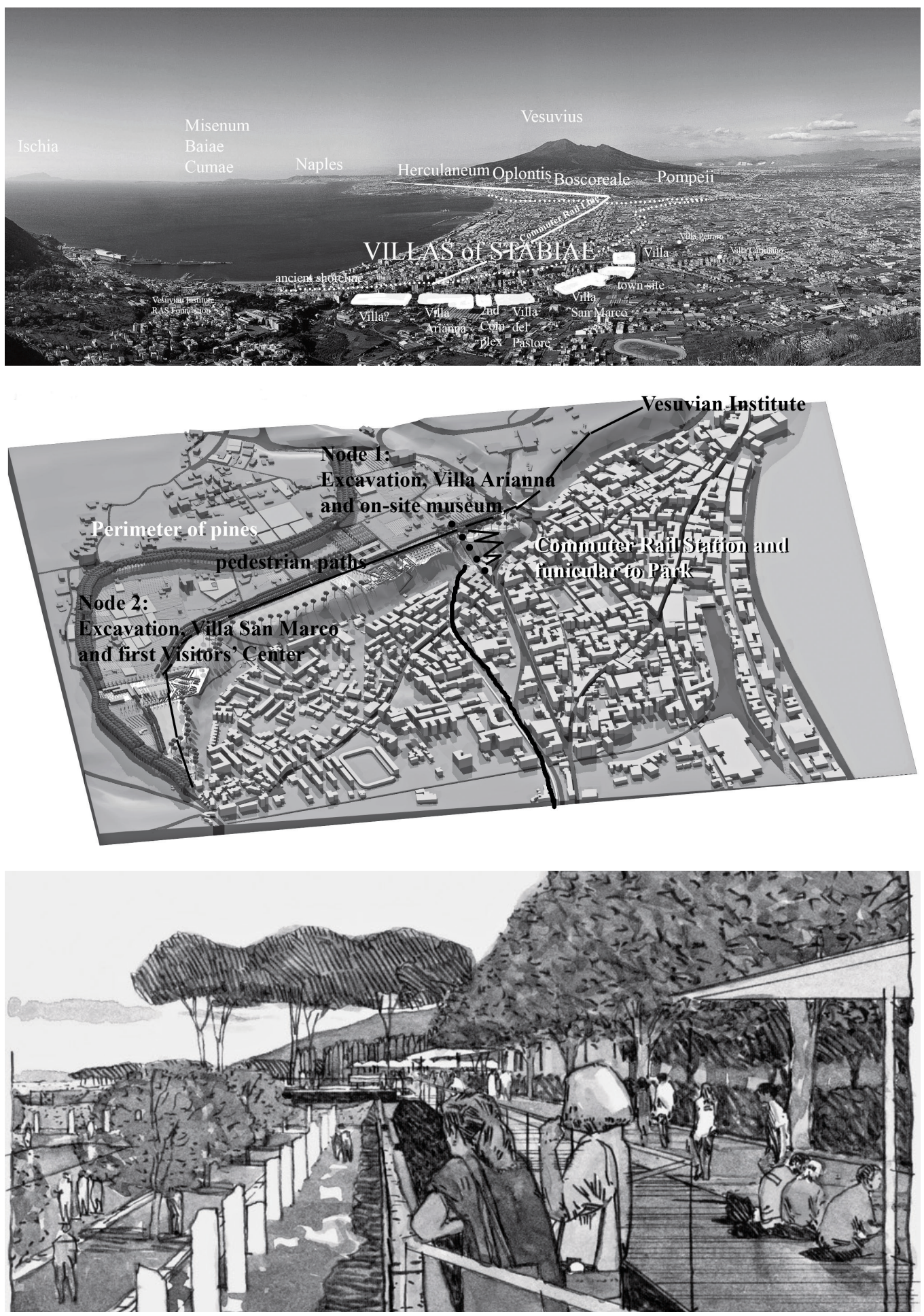
be maintained as such under the Master Plan. One of the biggest challenges of the site is that it is very difficult to access. Therefore, a successful archaeological park must propose urbanistic interventions.

\section{An "Archaeological Park"}

The term archaeological park is much abused today. A true archaeological park requires more than a fence around a ruin, but rather a concatenation of features which presents the ruin as embedded in coherent spatial and historical environment.

The concept of an archaeological park may go back — in part — to the American National Parks (Yellowstone, 1872), and perhaps, somewhat surprisingly, the American Civil War Battlefield parks [16 (on national Military parks - 16, p. 104); 12; 3, p. 17-23], and then - to the large areas of Rome laid out along the Via Appia after 1870 [4]. The idea of all of these was to preserve an all-enveloping coherent environment, not just isolated monuments. They offered a complete immersion into another period ambience and opened up new understanding of the interrelationships of ancient intuitions in actual space.

The American War Department, ironically enough, had a highly practical "archaeological" reason for preserving some of the great battlefields of the Civil War: the training of officers in battle tactics. When the overall terrain of a battlefield, for which there are precise hour by hour accounts, is preserved, with its areas of open field and closed forest preserved as they were - the hills which mask views or create overlooks, and the lines of roads - one can much better appreciate the technicalities of strategic decisions, errors of misinformation which the battle involved. Recovering the total environment of the Roman villa elite has much the same intention.

Recovering the total environment of an ancient site: The crucial new element of the innovative architecture of the Roman villas in the first century BC was the exploitation of the spectacular panoramic views of the Bay of Naples, and the integration of architecture with urbane Greek culture, gardening, music, poetry, baths, philosophy, dance, local cuisine and wine. As Madame de Stäel said, "Nothing... gives a more voluptuous idea of life than this climate which intimately unites man to nature" [17, book XI, ch. I]. Statius' and Pliny's discussions of the villas at Sorrento and Laurentum make it clear that the artful manipulation of sensations of nature was deeply felt in the generations when the villas were built [Statius, Silvae, 2.2; Pliny t.Y., 2.15; 5.6.]. Only at Stabiae can archaeology come close to recovering the total environment of any of these villas of the Roman elite.

\section{Definition of an "archaeological park":}

For the purpose of the RAS Master Plan, an archaeological park was defined as:

- a site with a coherent primary character;

- a site which represents a significant phenomenon of history and which preserves a good measure of the original orientation of ruins to the total environment, manmade and natural;

- a site with fairly well-preserved remains, which are, or can be made, "legible" to attentive visitors, and which can be maintained with visitors present;

- a site which is largely unencumbered by modern buildings or other intrusions from outside the main historical period; 
- there must be a concentration of activities on or adjacent to the site (e.g., museum, tours, outreach, "ancient" dining, events/concerts, bookstores, research, etc.);

- a number of visitors which is keyed to the volume which the site can manage;

- a site which can be integrated with its region, both in terms of modern infrastructure (access), culture and economy, and, ideally, be integrated with other related archaeological sites of the region;

- a site which can be supported in a sustainable manner by a long-term institutional infrastructure.

Very few archaeological sites offer this concatenation of features (which argues perhaps that most should be protected by reburying). The Stabiae site offers them all. The Stabiae site may offer the possibility of autonomous financial sustainability. It is, in effect, an easy site to «sell» to a large public as well as to the scholarly world. It should therefore eventually have a high chance of being financially auto-sustainable with visitor fees, much more so than most other sites. The site presents special challenges which must be met by ambitious projects, particularly access, in order for it to function as a true archaeological park. The 2001 Master Plan aims to meet these challenges by the following planning approaches.

\section{Planning Approaches:}

Integrated interdisciplinary approaches: From the outset, it was clear that the creation of an archaeological park on the site of the ancient Roman villas of Stabiae would require immense ambition and a highly integrated interdisciplinary approach. It would have to coordinate complicated activities in archaeology, architecture, urban planning, cultural property management and other disciplines. All must work together to make the undertaking succeed $^{8}$. A large excavation without easy public access or long-term maintenance would fail.

Access and orientation: A major challenge of the site is access. The Bay of Naples is a confusing, disorienting sprawl, and so is modern Castellammare di Stabia. Fortunately enough, the Stabiae site lies directly over the local commuter rail station, but when one arrives at the station today the site is wholly obscured. A funicular from the station could make the site accessible to tourists from Pompei in ten minutes (fig. 2). There is also ample open space within the park, and on its perimeter, for extensive parking, privately or state owned. Parking can be made sufficient for visitors or evening events.

Visibility from afar: The site is almost invisible in the urban sprawl of the Naples area, but a perimeter of traditional pines could mark it out as a unity even from a distance. Evening illumination on buildings and roofing along the top of the cliff could make it the "crown" of Castellammare. The ancient villas were highly visible from Pompeii, as they would be again, in a different way, through this landscaping and "son et lumière".

The spatial character of the ancient villas should dominate the spatial experience: No large constructions will be permitted on the brow of the hill; support buildings must be built

$8 \quad$ The "archaeological park" being created on the site of the ancient Roman villas of Stabiae (modern Castellammare di Stabia) is in the process of becoming one of the largest archaeological projects in Europe. Initial estimate in 2001 was approximately $€ 140$ million. This included several major excavations, an onsite museum, administrative and storage buildings, landscaping, land purchase, and urban connections. 
behind. Instead the original spatial arrangements of the villas should dominate the site so that the brow of the hill should represent only very low-key landscaping over the buried villas and the actual spaces of the excavated ones. The site would be an open panoramic promenade connecting the two principal nodes of the fully excavated villas Arianna and San Marco (fig. 3). A visit to the site, with its cool breezes and panoramas, would be radically different from a visit to Pompeii, and would be a key to an essential feature of the villa: the artful manipulation of refreshing environment by skillful architects.

Dual experience of Roman spatial design: The site will therefore offer a dual spatial experience: one which is "observational", as visitors walk on the unexcavated volcanic cinder and look down 4 meters into the villa floors (fig. 3); and one which is "immersive", in which visitors are in the villas and have the original experience of the focused cross-axial views created by the upstanding architecture.

Suggestive reconstruction: The roofing should suggest the volumetric massing but not attempt to reconstruct it since this cannot be known with "philological" certainty. RAS has proposed non-invasive suggestive reconstruction of the collapsed terraces at the front of the villas by light scaffolding design, in effect "sketching lightly" on the site.

Integration with modern urban environment: only the three fully excavated villas need to be secured area within the park and the rest of the Park should remain in private hands and in traditional cultivation, or areas open to the public when the villas are closed. The perimeter (marked by the curving road, fig. 2) can be developed for low-impact archeo-tourism by private investment: hiking; visiting sites; agricultural and artisanal products. The site should be traversed by public paths so that the park becomes an urban park even when the villas are closed, and connect the city to the area on the plateau, and not a barrier within the city.

Events: The site, with its potential for both road access with parking, and rail access, has considerable space on the unexcavated areas for evening events, such as "concerts with a view", and a museum and interactive visitors' center, either on or on the perimeter, of the site. The site is large enough so that there could be a separate concert at each "node" (the Villa San Marco or the Villa Arianna) without interfering with each other.

Cultural panorama of early Imperial Rome: Finally the site must function together with the other sites of the Vesuvian area to present a coherent panorama of early Imperial Roman culture: the small town sites of Pompeii and Herculaneum; the "rustic" farm villas best represented at Boscoreale; the Naples museum (Museo Archeologico Nazionale di Napoli); and the elite villas represented at Oplontis, the Papyri and above all the full enclave at Stabiae.

Catalyst for economic revival: This coordinated cultural panorama offers the justification for a multi-day stay for a serious cultural tourist. By contrast today, for the 2.5 million tourists who visit the Vesuvian area today, the average visit to the area (i.e. Pompeii) is 2.5 hours. Therefore archaeology may offer the possibility of being the catalyst of economic revival to a culturally rich but economically depressed area.

\section{History of the site and the Foundation}

The site is well-preserved also because the Italian government made it a protected archaeological zone in 1957. Total area within the legally designated zone is ca. 47 hectares. 
The total area of the villas, known and unknown, may be more than a quarter of that. The site was first excavated from 1749 to 1782, reburied and forgotten, though excellent plans were published in 1881. It was then rediscovered and partly re-excavated from 1950 by a local high school principal, and in the 1960s excavation passed to the Superintendancy of Pompei'. The RAS Foundation was launched in 1998 under the University of Maryland and the American Academy of Rome, and produced the Master Plan for the Soprintendenza Archeologica di Pompei (later Soprintendenza Speciale per i Beni Archeologici, di Napoli e Pompei, SANP) ${ }^{10}$ in 2001, and then from 2002 became a new type Italian non-profit foundation with international board representation from the Soprintendenza, the University of Maryland School of Architecture, Preservation and Planning, and a group of local supporters called the Committee of Stabia Reborn [first publications of the Master Plan: 11, pp. 189-194; 10, pp. $95-104]^{11}$. The Foundation is a new type of cultural non-profit ("onlus") in Italy, the first one created under law D. Lgs 368.98 which allows the Foundation to receive and spend both state and private funds from Italy and abroad, and it was created to assist the Superintendancy in the long term coordination of work and eventual management of certain activities on the park. It was created as a permanent foundation, not a short-term excavation or conservation or construction project alone. Major excavations and construction have been under way since 2006/07, executed both by archaeologists contracted by the Superintendancy, and by the RAS Foundation and its partners.

Activity of the RAS Foundation and Superintendancy since 2001:

- Founded as a non-profit in Italy in 2002, since 2007 the RAS Foundation, together with the Soprintendenza Speciale per i Beni Archeologici, di Pompei, Ercolano e Stabia (SS-PES), has:

- created an overall Master Plan (RAS, Maryland, American Academy in Rome, 2001);

- discovered, through the first successful geophysical survey in the Vesuvian area, the full extent of the Villa San Marco (22,000 sq. m, 2002, RAS), demonstration by excavation by sondage (2006, SAP);

- curated and organized the four-year tour of frescoes from Stabia, "In Stabiano", the first long-term loan of antiquities from Italy to the US under a 2002 Memorandum of Understanding in order to stem the purchase of illicit antiquities in the US;

- funded and planned and constructed the first phase of the first visitors' center (RAS, 2007 to present);

- funded and planned the excavation of the entrance courtyard of the Villa San Marco, (2007-2008, planning funding RAS; excavation, SS-PES contractors);

\footnotetext{
9 A brief and accurate summary of the history of the investigations of the site are found in the guidebook by the current and past directors of the site [5, pp. 21-31; 14, p. 17-22; 6, pp. 69-72]. The plans, done largely by royal engineer Karl Weber before his death in 1762, were later published by the director of excavations in Pompei, M. Ruggiero [15]. The principal records of the excavations done in the 1950-s are the day books of Libero D'Orsi, principal of the local classical high school [13].

10 The importance of Stabiae to the Vesuvian region was finally officially recognized by another name change for the Superintendancy, now known as the Soprintendenza Speciale per i Beni Archeologici, di Pompei, Ercolano e Stabia.

11 The Master Plan 2001 was presented to the Superintendancy, as its title suggests, in 2001.
} 
- $\quad$ excavated the cliff-edge of the townhouse next to villas San Marco (2009, SANP);

- $\quad$ re-roofed most of the Villa San Marco and Villa Arianna (2012-2013, SS-PES);

- $\quad$ fenced most of the site (2011-2013, SANP);

- $\quad$ conducted geophysical study of the geology of cliff edge (2007, Consortium INNOVA);

- excavated and published the large formal garden of the Villa Arianna, the first archaeological evidence of the existence of a type of garden seen previously only on the Prima Porta frescoes (2007-2013, SANP, RAS, with partners from University of Maryland; Cornell University; Univ. Tennessee; Univ. Mississippi; Univ. Birmingham; Univ. Brock; Univ. London; CNRS, France, Stockholm, Southwestern Univ.);

- re-excavated and conserved the thermal complex of the Villa Arianna (The State Hermitage Museum, Russia, and RAS, 2010-2014);

- first extensive stratigraphic excavations below the AD 79 level (RAS/Columbia University, 2011-2014);

- $\quad$ study of marble in the Stabiae villas (2013-2015, RAS/Univ. Akron);

- 3D digital recording of architecture, and LiDAR scanning, (2011-2014, RAS/Maryland, RAS/CyArk Oakland);

- conservation of Second Style frescoes in Villa Arianna (RAS/Academy of Fine Arts, Warsaw, 2015 ongoing).

\section{Funding Priorities:}

- five priority projects: Five multi-million $€$ large scale excavation and conservation projects to complete the major excavations required to open two large villas and one smaller one to the full extent required by the Master Plan: Villa San Marco Nymphaeum; Villa San Marco Upper Peristyle with 60 meters of preserved ceiling frescoes; Second Complex; Villa Arianna, Great Peristyle Garden (to completion); Villa Arianna, central block;

- comprehensive geotechnical survey and site work to stabilize the cliff edge and control moisture;

- $\quad$ endowment to establish permanent research and archive staff and study abroad center with innovative synchronous distance learning;

- completion of the Visitors' Center begun in 2007.

\section{Institutional support/long term loans of antiquities to institutional partners, permanent foundation:}

Finally, the RAS Foundation has steadily developed an institutional structure to create a permanent semi-private institution to assist the Italian government with the sustainable management of the site. The RAS Foundation is covered by a 2002 Memorandum of Understanding which declares that any institution in the US which supports the RAS Foundation in the study or maintenance of the Stabiae site may earn the right to request longterm loans of antiquities from Italy. US museums and universities may now build collections in a totally innovative way: by rotating collections of antiquities from Italy.

And very significantly, in 2007, the RAS Foundation took into its management a 90-room modern study college in Castellammare near the site to serve as an international 
study abroad and research center. This center since then has hosted over a hundred university and other study groups from numerous countries (most of Europe, the US, Brazil, Russia, etc.). The Foundation therefore has connected archaeology to conservation, urban planning and sustainable cultural properties management.

Title. The Archaeological Park at Stabiae: a Regional Interdisciplinary and Sustainable Approach.

Authors: Thomas Noble Howe - Professor, coordinator general. Restoring Ancient Stabiae Foundation, Southwestern University, University Avenue, 1001 E, 78626 Georgetown, TX, USA. howet@southwestern.edu

Paolo Gardelli - executive coordinator and archaeologist. Restoring Ancient Stabiae Foundation, Via Solaro, 13, 80053 Castellammare di Stabia (Na), Italy.pa.gardelli@gmail.com

Abstract. The site of Stabiae is a very unusual archaeological site. It was not just a site of great luxury or great art: it is the best-preserved example of one of the most important seats of political power and architectural art during the formation of the Roman Empire. Unlike Herculaneum or Oplontis, it is possible to excavate entire villas in their totality. First excavated from 1749 to 1782 , reburied and forgotten (though excellent plans were published in 1881), later it attracted very little public or scholarly attention before 1998 when the first steps were made to form the Restoring Ancient Stabiae Foundation. It was rediscovered and partly re-excavated from 1950 by a local high school principal, and in the 1960's excavation passed to the Superintendancy of Pompei, but it was RAS Foundation - a joint structure under the University of Maryland and the American Academy of Rome, and the Soprintendenza Archeologica di Pompei (later Speciale dei Beni Archeologici di Pompei e Napoli, SANP) that proposed the Master Plan of non-invasive suggestive reconstruction of the site for its further conservation, restoration and maintenance as an archaeological park. A true archaeological park requires a concatenation of features which presents the ruin as embedded in coherent spatial and historical environment, which are available at Stabiae. General principles and certain details of the project are presented and explained by the authors.

Keywords: the Naples Bay; the Vesuvian area; Stabiae; ancient Roman elite maritime villas; Restoring Ancient Stabiae (RAS) Foundation; University of Maryland; the American Academy of Rome; Soprintendenza Archeologica di Pompei, Soprintendenza Speciale per i Beni Archeologici, di Napoli e Pompei (SANP); Soprintendenza Speciale per i Beni Archeologici, di Pompei, Ercolano e Stabia (SS-PES); Soprintendenza Speciale dei Beni Culturali di Pompei, Ercolano e Stabia (SPES); Master plan; national secured historical area; archaeological park; restoring of Roman architecture; preservation of archaeological sites.

Название статьи. Археологический парк в Стабиях: междисциплинарный региональный и международный проект сохранения памятника.

Сведения об авторах. Нобл Хоу Томас - главный координатор проекта, профессор. Фонд Реставрации Древних Стабий. Юго-Западный университет. University Avenue, 1001 Е, Джорджтаун, 78626, Texac, США. howet@southwestern.edu

Гарделли Паоло - Фонд RAS, исполнительный директор, археолог, Виа Соларо, 13, 80053 Кастелламаре-ди-Стабия, Италия. pa.gardelli@gmail.com

Аннотация. Стабии - не вполне обычный археологический объект. Это не просто место обнаружения роскошных находок или выдающихся произведений искусства: это пример прекрасной сохранности памятника периода ранней Империи, одно из важнейших мест, где некогда обосновалась римская политическая элита, для которой возводились великолепные постройки. В отличие от Геркуланума или Оплонтиса виллы на этом памятнике можно раскопать практически целиком. За первыми раскопками, проводившимися с 1749 по 1782 г., наступил период заброшенности и забвения (правда, в 1881 г. были опубликованы очень хорошие планы), и в дальнейшем памятнику уделялось мало внимания как со стороны государства, так и научной общественности. Это продолжалось до 1998 г., когда были предприняты первые шаги к созданию Фонда реставрации древних Стабий (RAS). Новые исследования и частичные раскопки предпринимались начиная с 1950 г. директором местной средней школы, а в 1960-е гг. - Главным управлением по делам археологии в Помпеях, но именно RAS - общее детище Мэрилендского университета и Американской академии в Риме - в сотрудничестве с Главным управлением по делам археологического наследия Неаполя и Помпей (SANP) разработал перспективный мастер-план корректного восстановления памятника с целью его реставрации, консервации и дальнейшего использования в качестве археологического парка (заповедника). Для создания настоящего археологического 
парка необходимо такое сочетание характеристик объекта, при котором архитектурные руины могут быть сохранены в связном историко-культурном и пространственном контексте, что как раз и представляют собой Стабии. Общие принципы и значимые подробности проекта изложены в статье.

Ключевые слова: Стабии; приморские виллы древнеримской знати; Фонд реставрации древних Стабий (RAS), Мэрилендский университет; Американская академия в Риме; Главное управление по делам археологического наследия Неаполя и Помпей (SANP); Главное управление культурного наследия Помпей, Геркуланума и Стабий (SS-PES); мастер-план; национальные заповедники; археологический парк; реставрация античной архитектуры; реставрация и консервация археологических объектов.

\section{References}

1. Adam J.-P.; Frizot M. Dégradation e restauration de larchitecture pompéienne Institut de recherche sur larchitecture antique. Paris, Éditions du Centre National de la Recherche Scientifique Publ., 1983. 112 p. (in French).

2. Adams G. W. The Suburban Villas of Campania and their Social Function. British Archaeological Reports, International series, 1542. Oxford, Archaeopress Publ., 2006, pp. 9-24.

3. Albright H. M. Origins of the National Park Administration of Historic Sites. Philadelphia, Eastern National Park and Monument Association Publ., 1971, pp. 17-23.

4. Benevolo L. Roma. Studio per la sistemazione dellarea archeologica centrale. Lavori E Studi Di Archeologia. Roma, Leonardo Arte Publ., 1985. 120 p. (in Italian).

5. Bonifacio G., Sodo A. M. Stabiae, Guida Archeologica alle Ville. Castellammare di Stabia, N. Longobardi Publ., 2001. 215 p. (in Italian).

6. Camardo D. La riscoperta di Stabia negli scavi negli anni Cinquanta. Stabiae dai Borbone alle ultime scoperte. Castellammare di Stabia, N. Longobardi Publ., 2001, pp. 69-72 (in Italian).

7. Camardo D.; Ferrara A. (eds.). Stabiae dai Borbone alle ultime scoperte. Castellammare di Stabia, N. Longobardi Publ., 2001. 175 p. (in Italian).

8. Frazer A. (ed.). The Roman Villa. Villa Urbana. Philadelphia, University of Pennsylvania, Museum of Archaeology and Anthropology, Penn Press Publ., 1998. 120 p.

9. Howe T. N. The Architectural Evolution of the Villas of Stabiae, c. 80 BC-AD 79 (in press).

10. Howe T. N. The Master Plan for the Archaeological Park at Stabia. In Stabiano, Exploring the Ancient Seaside Villas of the Roman Elite. Castellammare di Stabia (Na), N. Longobardi Publ., 2004, pp. 95-104.

11. Howe T. N. Restoring Ancient Stabiae: Le Potenzialita' per un Parco Archeologico. Stabiae: storia e architettura. 250 anniversario degli scavi di Stabiae 1749-1999. Convegno internazionale Castellammare di Stabia 25-27 marzo 2000, Roma, „L'Erma“ di Bretschneider Publ., 2002, pp. 189-194 (in Italian).

12. Lee R. F. The Origin and Evolution of the National Military Park Idea. Washington DC, Office of Park Historic Preservation Publ., 1973 - Available at: http://www.nps.gov/parkhistory/online_books/ history_military/nmpidea7.htm (Accessed July 15, 2015).

13. D’Orsi L. Gli scavi di Stabiae. Ministero per i beni culturali ed ambientali, Soprintendenza Archeologica di Pompei. Monografie, vol. 11. Roma, Edizioni Quasar Publ., 1996. 520 p. (in Italian).

14. Rossano P. Le Esplorazioni settecentesche all'ombra di Vesuvio. Stabiae dai Borbone alle ultime scoperte. Castellammare di Stabia, N. Longobardi Publ., 2001, pp. 17-22.

15. Ruggiero M. Degli Scavi di Stabia dal MDCCLIX al MDCCLXXXII Degli Scavi ("On the Stabiae excavations from 1749 to 1782"). Napoli, 1881 (in Italian).

16. Runte A. The National Parks: The American Experience. Plymouth, UK, Taylor Trade Publishing, 2010. 336 p.

17. Stäel G. N. (Madame de Stäel) Corinne, or Italy. London, J. M. Dent \& Company Publ., 1894 (in Italian) [= Oxford, University Press Publ., 1999. 464 p. (in English)].

18. Wallace-Hadrill A. Villa as Cultural Symbol. The Roman Villa. Villa Urbana. Philadelphia, University of Pennsylvania Museum of Archaeology and Anthropology, Penn Press Publ., 1998, pp. 43-54.

19. Yegül F., Favro D. (eds.) Paradigm and Progeny: Roman Imperial Architecture and Its Legacy. Conference. In Honor of William L. MacDonald. The American Academy in Rome, December. 6-7, 2011. Available at: http://www.aarome.org/it/content/paradigm-and-progeny-imperial-architectureand-its-legacy (Accessed July 15, 2015).

20. Zarmakoupi M. Designing for Luxury on the Bay of Naples Villas and Landscapes c. 100 BCE - 79 CE. Oxford, Oxford University Press Publ., 2014. 312 p. 